\title{
Research on Museum Promotion Strategies in China
}

\author{
Zhao Yu, Guo Ying, Hu Nan, Xu Dan and Zhao Zhongliang \\ Beijing Institute of Petrochemical Technology
}

\begin{abstract}
Museum is the place for collecting, displaying and researching material objects standing for the natural and human cultural heritage, and the cultural education institution, building, site or social public institution providing the public with knowledge, education and appreciation. The promotion of museum is actually a kind of delivery of museum information, and good promotional strategies can better attract visitors to visit museums and realize the related functions of museums to educate the public. So it is very necessary to study on the promotional strategies of museum enterprises. At present, there are mainly three problems existing in the promotional strategies of museums: hysteretic promotional awareness, unitary promotional means and lagging media technologies. Corresponding solutions are put forward in the paper combining the characteristics of museum enterprises. Museum enterprises are expected to achieve the self-publicity effect through the rational design of promotional mix strategies, so as to enable museums to achieve "resplendence under magnificence".
\end{abstract}

KEYWORD: Museum; promotion; new media technology; solution

\section{INTRODUCTION}

Museum is the place for collecting, displaying and researching material objects standing for the natural and human cultural heritage, and the cultural education institution, building, site or social public institution providing the public with knowledge, education and appreciation. Museum shoulders the important cultural communication function to collect, protect, research and display human survival and environment physical evidences. As the product of social development and social needs, museum is the bridge linking the past, the present and the future, and its existence can meet the needs of social self-knowledge, continuity and development.

Promotion is marketers deliver various information related with their enterprises and products to consumers and persuade or attract consumers to purchase their products, to achieve the purpose of expanding sales. Promotion is a kind of communication activity in essence, namely marketers (information providers or senders) issue various information to stimulate consumption and pass information to one or more target objects (namely information receivers, like audiences, visitors, readers, consumers or users), to influence their attitudes and behaviors. Museum promotion is actually a kind of museum information delivery, and good promotion strategies can better attract visitors to visit museums, so as to realize the related functions of museums to educate the public.

How museums survive and develop in the current situation becomes a problem that museums of all levels need to focus on thinking. Someone called museums in modern cities as "loneliness in resplendent magnificence". The metaphor expressed the worries on the current development situation of various museums in China: The operation expenditure relies on government supply and cannot make end meet; the exhibition contents are disjointed with public demands and become "cultural relics" gradually; the service mode is unchanged for decades and fewer people come to visit. As non-profit organizations, museums should transform the stereotyped operating procedure, management ideas and thinking modes and strengthen their own marketing promotion through a series of marketing means like promotion and customer experience, so as to inject new vitality to the development of museums.

Therefore, it is very necessary to research the promotional strategies of museum enterprises. The main purpose of studying the promotional strategies of museums is to make the exhibits and cultural connotations of museums widely known and museum managers use promotional means to achieve the self-publicity effect under the marketing concepts, so as to make museums realize 
"resplendence under magnificence".

\section{EXISTING PROBLEMS}

Currently, Chinese museums meet the free opening age, but the free opening of museums makes the number of visitors increase sharply, increases the operation and management difficulty of museums, and poses severe challenges for Chinese museum industry as on the main party. How to better promote museums in the "free opening" policy and better serve visitors is the problem that museum managers must rethink. Currently, Chinese museums mainly have three aspects of problems in promotional strategies: hysteretic promotional awareness, unitary promotional means and lagging media technologies.

\subsection{Hysteretic promotional awareness}

The daily operation and business development of museums mainly depend on government investment. The effort on opening to the outside world is not strong enough, which leads to people's obsolete ideology and lagging marketing concepts, difficult to receive new ideology and culture, let alone active promotion. Besides, some museums generally "wait for policies, funds and visitors" due to ambiguous subordinate relationship or multiple management. They are seemingly active, but have fewer actions in marketing strategies and promotional strategies.

\subsection{Unitary promotional means}

Chinese museums all promote themselves by simple promotional forms now, and the main promotional forms include three aspects:

1) Free visit strategy. Starting from March 2008, the free visiting policy has been issued for museums under the jurisdiction of various cultural bureaus nationwide, which is the strongest promotional form at present. Of course, the promotion brought many problems, such as the surging visitor flow in large museums and too many visitors, unable to satisfy the visiting expectation of visitors.

2) Museums make simple promotions within their own scopes. Museums set out the display boards at the gate of museums before the exhibition of some special exhibits, place the leaflet column at the ticket changing window, play museum related video introduction at the LCD screen of the museum building, and the like, which are all museum promotions in the form of advertising.

3) Carry out promotions through selling books and souvenirs related with museums. The common problem of the promotion way is that this kind of products lacks characteristics and features unitary varieties and course workmanship. In addition to the difference in museum signs, many products sold by museums are copinism compared with the souvenirs of other museums and tourist souvenirs, only different in colors and textures, with fewer differences in functions and shapes, or they are whole-colored museum publications, postal cards, imitations, calligraphy and paintings, and folk handiwork. They are less competitive compared with the diversity of other cultural commodities.

The three promotion ways above are the most common in museums currently. In addition to this, there are fewer unique promotion ways that can attract the eyes of the masses, which greatly diminished the visiting groups of museums. We can find that the current promotional ways of museums are just for visitors interested in museums or visitors passing by related road sections. For the general social groups, museums did not make great promotions, which also lead to some people ignorant of some museums with very high-quality exhibits. Meanwhile, due to the rapid development of network informatization, some people choose to understand the history by clicking the mouse at home and lose the chances to directly face the valuable historical relics, which also restricted the development of museums and made the cultural industry lose the brilliance that it deserves.

\subsection{Lagging media technologies}

The current rapid development in various aspects of the society makes new media technologies achieve unprecedented progress. The arrival of the new media age thoroughly broke the spread pattern of traditional media and greatly changed the original spread pattern. The science communication of museum enterprises also faces the new media challenge. In the special period, various social media all emerge from the water and various platforms also rapidly rise via the internet. How to utilize these new media to add highlights to the promotion of museum enterprises? Many museum enterprises fail to pay much attention to the new field. Currently, some museum enterprises carry out WeChat marketing for promotion work, but in most cases, they give a kind of very coarse and random feeling. Most museum enterprises have weak awareness in utilizing new media technologies, which is unfavorable to the implementation of their media publicity and promotion in the future.

\section{SOLUTIONS}

Different from other tangible products, the products of the promotional strategies of museum enterprises are more a kind of experience and service, so they have basic features like inseparability, nonstorability, quality diversity and non-transferability of proprietorship. The difference of product features 
decided the different promotional strategies of museum enterprises.

When applying the promotional strategies, museum enterprises should first make their promotional targets clear, to build up the brand awareness of the enterprise or change customers' attitude towards the museum enterprise and attract the visitor flow. Secondly, they should correctly utilize proper promotional strategies and avoid blind promotion, which not only increased cost and also wasted resources, unable to fundamentally improve their performance. Museum enterprises should mutually supplement various promotional means through the rational design of the promotion mix, with the specific strategies as follows:

1) Assist academic institutions and student organizations like schools and scientific research institutions to carry out research and investigation in the way of cooperation. Such public relation activities can make museums communicate with more groups and individuals and expand the popularity of museums, so as to build museums assisting academic investigation and survey as a characteristic. Additionally, the survey related data can be obtained through cooperation, which is favorable to museums further improving operation strategies.

2) Museums should highlight their features according to the characteristics of their own exhibits and promote their features by such means as public transportation mobile media, WeChat setting and weibo platform information release or by multiple media mixes such as advertising advertorial and public service advertising.

3) Museum enterprises utilize physical exhibits to push network digital museums by multimedia forms like videos, voices and images. Through the digital museum, visitors can obtain the partial visiting experience in advance. Meanwhile, the communication platform for network visitors can be set to strengthen the interaction with visitors online. This way, network visitors can be attracted to experience the digital museum and more views and suggestions of visitors can be understood about the museum, to enable museums to make constant improvement and development.

4) Museums develop mobile applications based on their exhibit information and inset the voice explanation function in the mobile application for exhibits, which can attract museum visitors to have a more detailed understanding of exhibits and promote exhibits and museum enterprises based on obtaining good visiting experience.

5) Museums can regularly hold fun activities for visitors to participate, like museum knowledge interactive quiz and historical scene simulation, to make visitors obtain knowledge in fun and interesting participating process. The unique form can also attract more visitors to visit, especially children and teenagers.

6) Recruit and train museum volunteers, take advantage of volunteers providing interpretation services for museum visitors on the premise of effectively saving money, and utilize volunteers' social circles to promote museums, so as to achieve the promotion effect by the word of mouth.

7) Some museums that do not practice fee visit can cooperate with other cultural places like museums and theme parks and launch annual or quarterly coupon tickets to attract more visitors.

\section{CONCLUSION}

With the continuous development of the economy and the constant improvement of people's living standard, more and more people choose to visit museums to improve their cultural connotation, so how museum enterprises utilize promotional strategies to better publicize themselves and attract more visitors to visit so as to realize their function to educate the public is a critical problem that they need to solve. The paper analyzed the promotion status of museum enterprises, summarized the main problems existing in their promotional strategies and provided corresponding solutions and suggestions combining the characteristics of museum enterprises, in the hope that museum enterprises can use for reference, strengthen their own promotion through a series of promotion means, inject new vitality to the development of museums, and drive the service internationalization of Chinese museums.

\section{ACKNOWLEDGEMENTS}

This paper was funded by these projects: BIPTBPOYTMB-2013 and The URT program of Beijing Institute of Petrochemical Technology (2014J00103)

\section{REFERENCES}

[1] Chen Qingyi, Rustic Opinions on Museum Marketing, "Cultural Force and Museum Challenge" Shanghai China Maritime Museum Fourth International Symposium, August 2013, P7-17

[2] Xia Huaqing, Museum Marketing from the Perspective of Non-Profit Organizations, the master thesis of Jiangxi Normal University, June, 2010

[3] Tan Liping, On Museum Marketing under the Background of Free Opening, Hunan Museum Society 2010 Annual Meeting and Museum Free Opening Special Symposium Collected Papers, September 2010, P9-13

[4] Jiang Sheng, Study on Museum Commodity Marketing, Fudan University Master Thesis, May 2010

[5] Hu Jun, Reflect on Museum Marketing Activity Planning, Journal of Hunan University of Science and Engineering, September 2012, P68-69 